\title{
Osteocalcin, energy and glucose metabolism
}

\author{
Osteocalcina, metabolismo energético e da glicose
}

Leila C. B. Zanatta', Cesar L. Boguszewski', Victoria Z. C. Borba', Carolina A. M. Kulak'

1 Endocrine Division (SEMPR), Department of Internal Medicine, Universidade Federal do Paraná (UFPR), Curitiba, PR, Brazil

\author{
Correspondence to: \\ Carolina A. M. Kulak \\ Department of Internal Medicine, \\ SEMPR, Federal University of Parana \\ Av. Agostinho Leão Júnior, 285 \\ 80030-110 - Curitiba, PR, Brazil \\ kulakjc@gmail.com \\ Received on Mar/5/2014 \\ Accepted on May/15/2014 \\ DOI: 10.1590/0004-2730000003333
}

\begin{abstract}
Osteocalcin is a bone matrix protein that has been associated with several hormonal actions on energy and glucose metabolism. Animal and experimental models have shown that osteocalcin is released into the bloodstream and exerts biological effects on pancreatic beta cells and adipose tissue. Undercarboxylated osteocalcin is the hormonally active isoform and stimulates insulin secretion and enhances insulin sensitivity in adipose tissue and muscle. Insulin and leptin, in turn, act on bone tissue, modulating the osteocalcin secretion, in a traditional feedback mechanism that places the skeleton as a true endocrine organ. Further studies are required to elucidate the role of osteocalcin in the regulation of glucose and energy metabolism in humans and its potential therapeutic implications in diabetes, obesity and metabolic syndrome. Arq Bras Endocrinol Metab. 2014;58(5):444-51
\end{abstract}

\section{Keywords}

Osteocalcin; undercarboxylated osteocalcin; metabolic syndrome; glucose; energy metabolism; diabetes; obesity; leptin; insulin; adiponectin

\section{RESUMO}

A osteocalcina é uma proteína da matriz óssea que tem sido implicada com várias ações hormonais relacionadas à homeostase de glicose e ao metabolismo energético. Modelos animais e experimentais têm demonstrado que a osteocalcina é liberada do osso para a circulação sanguínea e age nas células betapancreáticas e no tecido adiposo. A osteocalcina decarboxilada é a isoforma hormonalmente ativa e estimula a secreção e sensibilidade à insulina no tecido adiposo e muscular. $A$ insulina e a leptina, por sua vez, atuam no tecido ósseo modulando a secreção da osteocalcina, formando uma alça de retroalimentação tradicional em que o esqueleto torna-se um órgão endócrino. Novos estudos ainda são necessários para elucidar o papel da osteocalcina na regulação glicêmica e no metabolismo energético em humanos, com potenciais implicações terapêuticas no tratamento de diabetes, obesidade e síndrome metabólica. Arq Bras Endocrinol Metab. 2014;58(5):444-51

\section{Descritores}

Osteocalcina; osteocalcina descarboxilada; síndrome metabólica; glicose; metabolismo energético; diabetes; obesidade; leptina; insulina; adiponectina

\section{INTRODUCTION}

$\mathrm{T}$ raditionally, the skeleton is responsible for the support and locomotion of an organism. However, besides its mechanical properties, bone has emerged as a regulator of a number of metabolic processes that are independent of mineral metabolism. In fact, the skeleton has been considered an endocrine organ because of its capacity to secrete osteocalcin, a bone-specific protein, which has been implicated in the energy and glucose homeostasis (2). In 1996, Ducy and cols. (1) described increased visceral fat and insulin resistance in osteocalcin-deficient mice $\left(\mathrm{Osn}^{-/}\right)$. 
These findings remained unexplained until 2007, when Lee and cols. (2) looked for genes expressed in osteoblasts encoding signaling molecules that could affect energy metabolism. These pioneering studies were the first to demonstrate the endocrine regulation of energy metabolism by the skeleton.

In this article, we review the current knowledge on the importance of the Embryonic stem cells phosphatase (Esp) gene, expressed in osteoblasts and Sertoli cells. It is responsible for the receptor-like protein tyrosine phosphatase [OST-PTP] synthesis - The Osteocalcin gene, which is exclusively coded by osteoblasts and is responsible for the osteocalcin production as well as the GPRC6A gene - coded by the pancreatic beta-cells and regulates osteocalcin receptor synthesis. Furthermore, the most relevant epidemiological and clinical studies that have shed light on osteocalcin and its association with energy and glucose abnormalities will be discussed.

\section{THE BONE AND ENERGY HOMEOSTASIS}

Hormone release is normally under control of endocrine feedback mechanisms between the site where the hormone is produced and the target organ or tissue where it acts. The adipocyte-derived hormone leptin is recognized as one of the most important regulators of bone remodeling, which emerged evolutionarily with the vertebrate animals (3). Ducy and cols. (4) discovered that leptin exerts a negative control on bone accrual mass, as leptin-deficient mice have a high bone mass, even in the presence of hypogonadism. This leptin effect is exerted through a hypothalamic relay using two neural mediators, the sympathetic tone and CART ('cocaine amphetamine regulated transcript'), both acting on the osteoblast (5). This effect involves leptin transportation through the blood-brain barrier and it's binding to specific receptors in serotoninergic neurons of brainstem, inhibiting the serotonin synthesis (6). The serotonin is a positive regulator of appetite and an inhibitor of catecholamine synthesis from hypothalamic neurons, actions that favor bone mass accrual (7). When leptin acts, appetite is inhibited and the central sympathetic tone is released. As a consequence, bone formation is impaired, since osteoblasts are inhibited when catecholamine binds to their beta-2 adrenergic receptors, as investigated only in animal models $(7,8)$ (Figure 1).

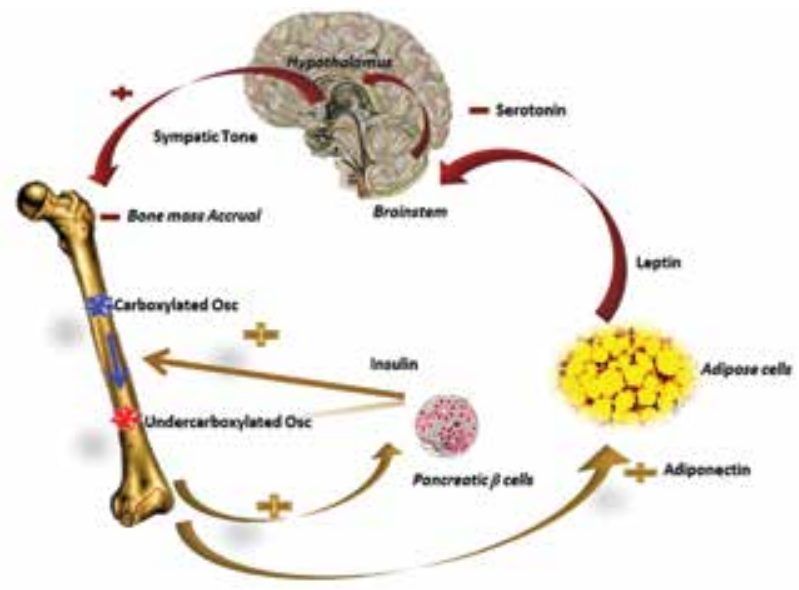

Figure 1. Endocrine feedback mechanism between bone and energy glucose metabolism. The leptine binding to serotoninergic neurons of brainstem, inhibiting the serotonin and releasing the central sympathetic tone. As a consequence, impairing the bone mass accrual and osteocalcin synthesis. In bone, the insulin stimulates the secretion of undercarboxylated osteocalcin, which improves the proliferation of pancreatic $\beta$ cells and insulin secretion, and increases adiponectin production on fat cells, resulting in increasing insulin sensitivity. Figure adapted from P. Ducy (Diabetologia. 54:1291-7).

\section{OSTEOCALCIN}

Osteocalcin is a 49 amino acid peptide synthesized exclusively by the osteoblasts and stored in the bone mineral matrix as hydroxyapatite crystals. It was recognized as a marker of bone formation at the time of its discovery and biochemical characterization (9). It is encoded by a specific gene codified in 1989 and located in the short arm of chromosome 12 (12p). The gene spans 3.9 kilobases of chromosomal DNA, with four exons separated by three large intervening sequences. Its promoter region reveals the presence of a number of putative regulatory sequences and vitamin $\mathrm{K}$ transcription factor responsive elements. The pre-pro-molecule consists of 84 amino acids that lose the propeptide in a vitamin k-dependent posttranscriptional process (10). It becomes gamma-carboxylated on three glutamic acid residues, forming the so-called Gla bone protein that has a high affinity to the hydroxyapatite mineral osteoid matrix (11).

The real physiological importance of the Gla bone protein is not completely understood, since animal models with gain or loss of its function do not show changes in bone phenotype. In a process of acidification of the bone mineral matrix in the reabsorption lacunae, the carboxylated osteocalcin would lose its glutamic acids. Therefore, reduces the bone affinity of the peptide and gives rise to undercarboxylated 
osteocalcin, the hormonally active form that is released into the bloodstream $(9,11,12)$.

The evidence for influence of osteocalcin in the glucose metabolism was demonstrated in $\mathrm{Osc}$ - /- mice. The phenotype of insulin resistance, hyperglycemia, obesity and lower energy expenditure observed in these animals is reversed by administration of osteocalcin. Undercarboxylated osteocalcin stimulates proliferation of pancreatic beta-cells and insulin secretion In vitro, and increases adiponectin production on fat cells, resulting in increased insulin sensitivity. Taken together, these actions reveal a positive feedback mechanism between pancreatic beta-cells, adipose tissue and bone, with the insulin enhancing the production of undercarboxylated osteocalcin, which in turn enhances insulin production and sensitivity $(13,14)$.

\section{EMBRYONIC STEM CELLS PHOSPHATASE (ESP) GENE}

The Esp gene encodes the osteotesticular protein tyrosine phosphatase (OST-PTP) in osteoblasts and Sertoli cells of mice (15). This protein is a transmembrane receptor highly regulated in bone cells and essential to osteoblast differentiation and mineralization. It was discovered in 1994 and subsequent studies implicated OST-PTP in the negative transcriptional regulation of insulin receptor in the osteoblasts $(15,16)$. Animal models with specific deletion of the Esp gene in the osteoblasts $\left(E s p^{-/}\right)$show beta-cell proliferation, increased insulin secretion and sensitivity, increased adiponectin concentrations and hypoglycemia. Esp ${ }^{-/-}$mice also exhibit high concentrations of undercarboxylated osteocalcin, indicating that OST-PTP negatively modulates the osteocalcin decarboxylation (16). This phenotype resembles that observed in osteocalcin knockout animals $\left(\mathrm{Osc}^{-/-}\right)$and is partly reversible with the deletion of one allele of the osteocalcin gene (2).

It has been shown that Insulin binds to its tyrosine kinase receptor expressed in osteoblasts and stimulates the production of undercarboxylated osteocalcin by two different mechanisms: [1] enhancing the osteocalcin gene transcription and [2] reducing the osteoprotegerin synthesis and the Esp gene expression $(15,16)$. Osteoprotegerin is the receptor that binds to RANKL on osteoblast/stromal cells, blocking the RANKL-RANK interaction and the osteoclast pre- cursors, with a consequent reduction of osteoclasts production and bone resorption $(17,18)$. As a consequence of low osteoprotegerin production, osteoclasts are stimulated, enhancing the acidification of the bone mineral matrix in the reabsorption lacunae and increasing the undercarboxylated osteocalcin release. In this process, the carboxylated osteocalcin loses its glutamic acids and, consequently, reduces its bone affinity, which facilitates its secretion into the bloodstream in a metabolically active isoform (Figure 2).

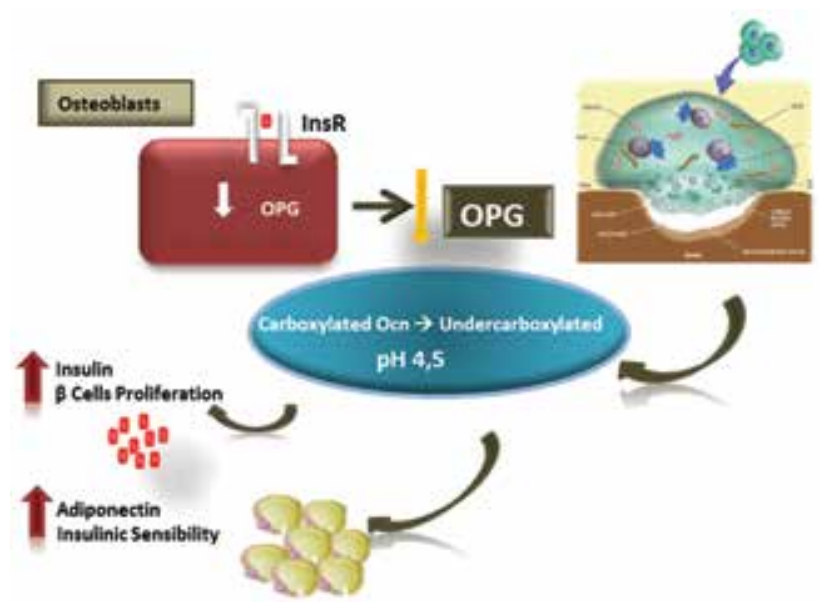

Figure 2. The insulin, acting in its receptor (InsR), stimulating the undercarboxylated osteocalcin (Ocn) secretion by osteoprotegerin (OPG) reduction and acidification of reabsorption lacunae. The undercarboxylated osteocalcin acting in $\beta$ cells and adipose cells. Figure adapted from Clemens and Karsenty (50).

\section{PTP1B: THE HUMAN EQUIVALENT PROTEIN OF OST-PTP}

Based on the well-established down regulation mechanism exerted by the PTP IB (protein tyrosine phosphatase) on the human insulin receptors present in myoblasts and hepatocytes, Ferron and cols. (17) postulated that human PTPIB would correspond to the OST-PTP seen in mice. Molecular analysis allowed that PTP $1 \mathrm{~B}$ performs in human osteoblasts the function that OST-PTP performs in mouse osteoblasts and recognized that its inhibition, uniquely in these animal cells, lead to the same phenotype observed by Lee in models Esp - / - . He proved that insulin signaling in human osteoblasts controls OPG expression as it does in mouse osteoblasts. Evaluating three patients with an autosomal dominant form of osteopetrosis they observed increase in osteocal- 
cin carboxylation and decrease in insulin blood level. The circulating undercarboxylated osteocalcin was significantly decreased in all patients, as were serum insulin levels measured after feeding. Thus, Esp gene product PTPIB inactivates the osteocalcin and interferes with the energy metabolism by inactivating the insulin receptor (Figures 3 and 4) (17).

\section{IDENTIFYING THE PANCREATIC RECEPTOR OF OSTEOCALCIN: THE ROLE OF GPRC6A}

The GPRC6A is a member of the G protein-coupled receptors sensitive to pertussis toxin. When activated, it is capable of phosphorylating key proteins of insulin secretory pathway in the pancreatic beta-cells (21). Min Pi and cols., studying animal model with GPRC6A deletion, observed a complex phenotype involving multiple systems and including osteopenia, hepatic steatosis, glucose intolerance and insulin resistance (22). These authors postulated that pancreatic beta-cells could have an equivalent of this receptor, sensible to the actions of undercarboxylated osteocalcin. From several experiments using human embryonic cells, mouse pancreatic beta-cells and GPRC6A deficient mice, they found that GPRC6A mediates responses to osteocalcin in beta-cells in $v i^{-}$ tro and pancreas in vivo. These preliminary data suggested GRPC6A as the biologically relevant receptor for osteocalcin on human pancreatic beta-cells (23).

\section{BONE AS AN ENDOCRINE ORGAN: HUMAN STUDIES}

Epidemiological studies in humans have been carried out to examine the association between osteocalcin and several metabolic parameters, such as glycaemia, insulin secretion, lipid profile, visceral fat, body mass index and vascular inflammation. These studies have added information on the potential impact of the skeleton, via osteocalcin, in the energy regulation and glucose metabolism.

\section{Osteocalcin levels and metabolic parameters in humans}

Jee-Aee and cols. (24) investigated the association between osteocalcin and glycemic indexes in 339 postmenopausal women with and without diabetes. They found a significant association between higher serum levels of osteocalcin with insulin sensitivity (estimated by the homeostasis model assessment of insulin resistance index - HOMA-IR), lower glycemic index and glycated hemoglobin ( $\mathrm{HbAlc})$. In addition, osteocalcin concentrations were significantly lower in patients with diabetes.

The MrOS study from Sweden, evaluated over 1,000 diabetic and non-diabetic elderly men (mean age 75 years-old) and found that serum osteocalcin levels were an independent negative predictor factor for plasma glucose concentrations, according previous data in animal models (25). Posterior crosssectional analysis involving 380 adults aged 65 years or more found a negative correlation between metabolic parameters and osteocalcin levels (26). In this report, 198 patients were followed for three years and those with high basal levels of osteocalcin had lower increase in plasma glucose during the follow -up (26). These results were later corroborated by a large cohort study that evaluated more than 2,760 elderly men and found lower levels of osteocalcin in the presence of metabolic syndrome, as well as worse glycemic and insulin sensitivity indexes (27).

Kanazawa and cols. demonstrated an inverse correlation between higher levels of osteocalcin and markers of atherosclerosis (lower ankle-brachial in-

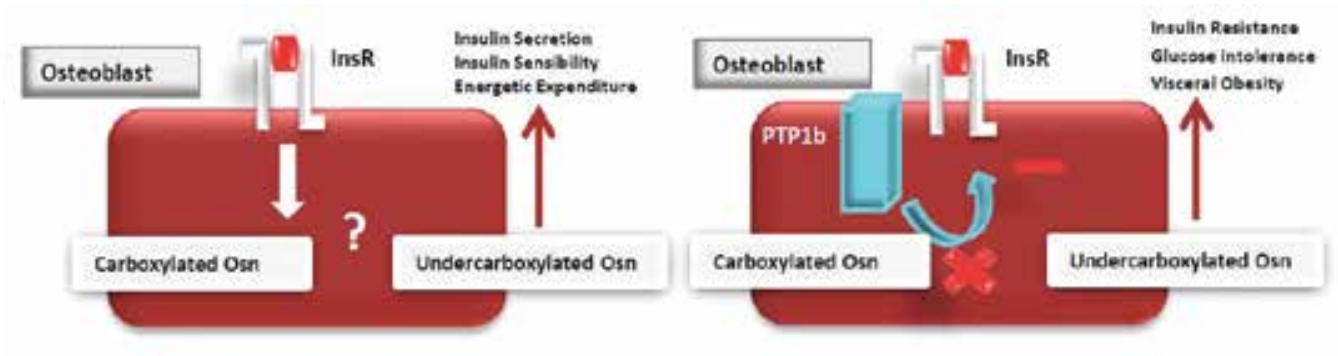

Figures 3 and 4. The insulin stimulating the undercarboxylated osteocalcin synthesis in osteoblast and improving the insulin secretion, sensibility and energetic expenditure. PTP1B inhibiting the undercarboxylated osteocalcin secretion and leading to insulin resistance, glucose intolerance and increasing visceral adiposity. Figure adapted from Clemens and Karsenty (50). 
dex and increased intima-media thickness), suggesting that osteocalcin might be implicated in the atherosclerotic disease (28). Other observational study in 102 patients younger than 40 years old identified a negative association between osteocalcin levels and acute myocardial infarction (29). In a Chinese study with more than 500 individuals with and without diabetes, a negative correlation between osteocalcin levels and lipid metabolism was observed (30).

García-Martín and cols. (31) conducted a study in 54 healthy non-diabetic postmenopausal women to investigate whether serum osteocalcin could be a marker of metabolic risk. They found a positive association between osteocalcin with fasting glucose, LDL cholesterol and obesity, and also reported on that serum osteocalcin concentrations lower than $13.5 \mathrm{ng} / \mathrm{mL}$ have a sensitivity of $85.7 \%$ and specificity of $63.8 \%$ in detecting increased risk of diabetes.

Osteocalcin levels and insulin sensitivity were correlated in a small group of obese women, who were subjected to intervention with hypocaloric diet and/or physical activity for 16 weeks (32). The results showed that physical activity provided a better response in the elevation of serum osteocalcin than diet alone, even with a lower weight loss in the former group. The reduction of visceral fat was the best independent predictor of change in osteocalcin levels, which was positively correlated with insulin sensitivity. Taken together, these results would suggest that physical activity improves insulin sensitivity by increasing serum osteocalcin levels (32).

A large observational study correlated osteocalcin levels with adipokines (leptin and adiponectin) and markers of metabolic syndrome, body fat and physical activity (33). A total of 1,284 Afro-Americans and 1,209 non-Hispanic whites individuals were evaluated and, in both populations, osteocalcin was inversely related to leptin and metabolic markers, such as body mass index, waist circumference, blood glucose, insulin and triglycerides, and directly related to adiponectin. In this study, the worse the severity of the metabolic syndrome the lower levels of osteocalcin were found, independently of the glycemic changes (33). More recently, Bao and cols. (34) confirmed in a large cohort of Chinese men that visceral fat was inversely related to osteocalcin levels, independently of blood glucose and total body fat.

The association between glucose homeostasis and osteocalcin was also investigated in women with gestational diabetes mellitus (GDM). Interestingly, the results were not consistent with studies in other populations. Osteocalcin levels were elevated in GDM compared to non-diabetic pregnant women and they normalized in the postpartum period. It has been suggested that these findings would correspond to an adaptive mechanism to fight against the insulin resistance of GDM, but a direct effect of hyperinsulinemia on osteocalcin secretion could not be ruled out during this period (35).

\section{Human studies involving undercarboxylated osteocalcin}

Epidemiological studies have specifically examined the association of metabolic parameters with serum undercarboxylated osteocalcin levels, the hormonally active form of osteocalcin, but the results are not uniform and were not demonstrated in all studies (36-40). An important limitation of these studies is the lack of homogeneity and established specificity of commercially available assays to detect the undercarboxylated osteocalcin isoform (41-43).

Hwang and cols. (36) found a significant association of higher tertiles of undercarboxylated osteocalcin levels with the lowest glycemic indexes and improved insulin sensitivity. Corroborating these findings, a study involving 180 diabetic men demonstrated an inverse correlation between undercarboxylated osteocalcin and fasting glucose, HbAlc, total body and visceral fat. However, these associations were not observed in a group of postmenopausal women (37).

Schafer and cols. (44) investigated if the osteoporosis treatment could influence the undercarboxylated osteocalcin levels and its impact on body fat and glycemic indexes. In their study, the therapeutic use of human recombinant parathyroid hormone (hrP$\mathrm{TH}$ 1-84) and alendronate were compared in 97 osteoporotic postmenopausal women. The anabolic treatment with hrPTH 1-84 increased undercarboxylated osteocalcin levels after three months, whereas the anti-resorptive treatment with alendronate reduced them. The elevation of undercarboxylated osteocalcin was inversely related to body weight and total fat mass after 12 months of treatment, and directly related to adiponectin increase. There was no correlation with leptin levels or glycemic indexes (44).

An interventional study in 28 obese middle-aged men, with and without diabetes, submitted to 
two types of exercise (aerobic and power), examined the changes in glucose levels, HbAlc, adiponectin, undercarboxylated and total osteocalcin, pre and post-exercise. The two types of exercise were effective in reducing the glycemic index, but only aerobic activity was able to increase undercarboxylated osteocalcin. In the subgroup with diabetes, the increased percentage of undercarboxylated osteocalcin was the main predictor of the reduction of glucose levels after exercise. These results suggested that improvement of glucose metabolism after exercise could be partly explained by the increase of undercarboxylated osteocalcin (45).

Pollock and cols. (46) assessed changes in bone mineral density (BMD), glycemic and lipid indexes, levels of undercarboxylated and total osteocalcin, and central adiposity in children with and without pre-diabetes. A group of 140 sedentary overweight children were subjected to an intervention with physical activity for six months. The pre-diabetes subgroup had lower total body BMD, independently of the total weight, with an inverse correlation between BMD and the visceral and subcutaneous abdominal fat. Subsequently, the same group of researchers (47) reported on lower levels of undercarboxylated and total osteocalcin in the pre-diabetes children, who also exhibited worse insulin secretion and insulin sensitivity indexes. The authors suggested that lower undercarboxylated osteocalcin levels in pre-diabetic children may be partly responsible to impairment of beta-cell function. In agreement, other group of researchers showed that weight loss in obese children is associated with improvement on insulin sensitivity and elevation of serum osteocalcin concentrations (48).

\section{OSTEOCALCIN: A POTENTIAL THERAPY FOR METABOLIC SYNDROME AND TYPE 2 DIABETES?}

The experimental and epidemiological data available to date suggest a role of undercarboxylated osteocalcin as a positive modulator of insulin secretion and sensitivity. As mentioned by Ducy (49), Clemens and Karsenty (50), we are now dealing with a new pharmacological perspective, as osteocalcin may have a positive impact in the therapy of metabolic syndrome and diabetes mellitus. However, there is a long way to pursue, as up to now no clinical trial using osteocalcin in humans has been published and even in animals, the osteocalcin administration have been tested in only two models (19).

In the first model, subcutaneous infusion of osteocalcin was administered to mice subjected to a high-fat diet, resulting in less weight gain, improved insulin sensitivity and glycemic index, and correction of hypertriglyceridemia, in comparison with paired mice treated with vehicle (19). In the second model, mice with hyperphagia induced by damage of the arcuate nuclei and treated with recombinant osteocalcin had lower weight gain and improved insulin sensitivity in comparison to controls. Mice treated with osteocalcin remained euglycemic, in contrast to the other group treated with vehicle, which became obese and developed metabolic syndrome. In both experimental models, the beneficial effects of osteocalcin on carbohydrate metabolism occurred without changes in appetite, consistent with the lack of osteocalcin effect on the leptin gene expression (19).

\section{CONCLUSION}

The discovery of osteocalcin has opened a new perspective on the interactions between the skeleton and several tissues associated with energy homeostasis and glucose metabolism, such as pancreatic beta-cells, adipose tissue and the brain, confirming the bone as a true endocrine organ. The results with osteocalcin are more evident than the undercarboxylated isoform, probably due the lack of standardization of the assays. All the knowledge on the components of these new hormonal loops, shed light on the potential for new therapeutic interventions for high prevalent endocrine disorders, such as obesity, diabetes and metabolic syndrome.

Disclosure: no potential conflict of interest relevant to this article was reported.

\section{REFERENCES}

1. Ducy P, Desbois C, Boyce B, Pinero G, Story B, Dunstan C, et al. Increased bone formation in osteocalcin-deficient mice. Nature. 1996;382:448-52.

2. Lee NK, Sowa $H$, Hinoi E, Ferron M, Ahn JD, Confavreux $C$, et al. Endocrine regulation of energy metabolism by the skeleton. Cell. 2007;130:456-69.

3. Jackson MB, Ahima RS. Neuroendocrine and metabolic effects of adipocyte-derived hormones. Clin Sci (Lond). 2006;110(2):143-52.

4. Ducy $P$, Amling M, Takeda S, Priemel M, Schilling AF, Beil FT, et al. Leptin inhibits bone formation through a hypothalamic relay: a central control of bone mass. Cell. 2000;100:197-207. 
5. Karsenty G. Convergence between bone and energy homeostases: leptin regulation of bone mass. Cell Metab. 2006;4:341-8.

6. Karsenty G, Oury F. The central regulation of bone mass, the first link between bone remodeling and energy metabolism. J Clin Endocrinol Metab. 2010;95:4795-801.

7. Yadav VK, Oury F, Suda N, Liu ZW, Gao XB, Confavreux C, et al. A serotonin-dependent mechanism explains the leptin regulation of bone mass, appetite, and energy expenditure. Cell. 2009;138:976-89.

8. Takeda S, Elefteriou F, Levasseur R, Liu X, Zhao L, Parker KL, et al. Leptin regulates bone formation via the sympathetic nervous system. Cell. 2002;111:305-17.

9. Hauschka PV, Lian JB, Cole DE, Gundberg CM. Osteocalcin and matrix Gla protein: vitamin K-dependent proteins in bone. Physiol Rev. 1989;69:990-1047.

10. Cancela L, Hsieh CL, Francke U, Price PA. Molecular structure, cromosome assignment and promoter organization of the human matrix Gla protein gene. J Biol Chem. 1990;265(25):15040-8.

11. Engelke JA, Hale JE, Suttie JW, Price PA. Vitamin K-dependent carboxylase: utilization of decarboxylated bone Gla protein and matrix Gla protein as substrates. Biochim Biophys Acta. 1991;1078:31-4.

12. Price PA. Gla-containing proteins of bone. ConnectTissue Res. 1989;21:51-57, discussion 57-60.

13. Ferron M, Hinoi E, Karsenty G, Ducy P. Osteocalcin differentially regulates beta-cell and adipocyte gene expression and affects the development of metabolic diseases in wild-type mice. Proc Natl Acad. Sci. U.S.A. 2008;105:5266-70.

14. Ducy P, Zhang R, Geoffroy V, Ridall AL, Karsenty G. Osf2/ Cbfa1: a transcriptional activator of osteoblast differentiation. Cell. 1997;89:747-54.

15. Lee K, Nichols J, Smith A. Identification of a developmentally regulated protein tyrosine phosphatase in embryonic stem cells that is a marker of pluripotential epiblast and early mesoderm. Mech Dev. 1996;59:153-64.

16. Mauro LJ, Olmsted EA, Skrobacz BM, Mourey RJ, Davis AR, Dixon JE. Identification of a hormonally regulated protein tyrosine phosphatase associated with bone and testicular differentiation. J Biol Chem. 1994;269:30659-667.

17. Ferron M, Wei J,YoshizawaT, Del Fattore A, DePinho RA, Teti A, et al. Insulin signaling in osteoblasts integrates bone remodeling and energy metabolism. Cell. 2010;142(2):296-308.

18. Yoshizawa T, Hinoi E, Jung DY, Kajimura D, Ferron M, Seo J, et al. The transcription factor ATF4 regulates glucose metabolism in mice through its expression in osteoblasts. J Clin Invest. 2009;119:2807-17.

19. Teitelbaum SL, Ross FP. Genetic regulation of osteoclast development and function. Nat Rev Genet. 2003;4(8):638-49.

20. Harada S, Takahashi N. Control of bone resorption by RANKL -RANK system. Clin Calcium. 2011;21(8):1121-30.

21. Wellendorph $P$, Brauner-Osborne $H$. Molecular cloning, expression, and sequence analysis of GPRC6A, a novel family C G-protein-coupled receptor. Gene. 2004;335:37-46.

22. Pi M, Chen L, Huang MZ, Zhu W, Ringhofer B, Luo J, et al. GPRC6A null mice exhibit osteopenia, feminization and metabolic syndrome. PLoS One. 2008;3(12):e3858.

23. Pi M,Yunpeng WuY, Quarles LD. GPRC6A mediates responses to osteocalcin in b-cells in vitro and pancreas in vivo. $\mathrm{J}$ Bone Miner Res. 2011;26(7):1680-3.

24. Im JA, Yu BP, Jeon JY, Kim SH. Relationship between osteocalcin and glucose metabolism in postmenopausal women. Clin Chim Acta. 2008;396(1-2):66-9.

25. Kindblom JM, Ohlsson C, Ljunggren O, Karlsson MK, Tivesten A, Smith U. Plasma osteocalcin is inversely related to fat mass and plasma glucose in elderly Swedish men. J Bone Miner Res. 2009;24:785-91.
26. Pittas AG, Harris SS, Eliades M, Stark P, Dawson-Hughes B. Association between serum osteocalcin and markers of metabolic phenotype. J Clin Endocrinol Metab. 2009;94:827-83.

27. Yeap BB, Chubb SA, Flicker L, McCaul KA, Ebeling PR, Beilby $\mathrm{JP}$, et al. Reduced serum total osteocalcin is associated with metabolic syndrome in older men via waist circumference, hyperglycemia, and triglyceride levels. Eur J Endocrinol. 2010;163(2):265-72.

28. Kanazawa I, Yamaguchi T, Yamamoto M, Yamauchi M, Kurioka S, Yano S, et al. Serum osteocalcin level is associated with glucose metabolism and atherosclerosis parameters in type 2 diabetes mellitus. J Clin Endocrinol Metab. 2009;94:45-9.

29. Goliasch G, Blessberger H, Azar D, Heinze G, Wojta J, Bieglmayer $\mathrm{C}$, et al. Markers of bone metabolism in premature myocardial infarction ( $\leq 40$ years of age). Bone. 2010;48:622-6.

30. Zhou M, Ma X, Li H, Pan X, Tang J, GaoY, et al. Serum osteocalcin concentration in relation to glucose and lipid metabolism in Chinese individual. Eur J Endocrinol. 2009;161(5):723-9.

31. García-Martín A, Cortés-Berdonces $M$, Luque-Fernández I, Rozas-Moreno P, Quesada-Charneco M, Muñoz-Torres M. Osteocalcin as a marker of metabolic risk in healthy postmenopausal women. Menopause. 2011;18(5):537-41.

32. Fernández-Real JM, Izquierdo M, Ortega F, Gorostiaga E, Gómez-Ambrosi J, Moreno-Navarrete JM, et al. The relationship of serum osteocalcin concentration to insulin secretion, sensitive and disposal with hypocaloric diet and resistance training. J Clin Endocrinol Metab. 2009;94:237-45.

33. Saleem U, Mosley JrTH, Kullo IJ. Serum osteocalcin is associated with measures of insulin resistance, adipokine levels, and the presence of metabolic syndrome. ArteriosclerThromb Vasc Biol. 2010;30(7):1474-8.

34. Bao Y1, Ma X, Yang R, Wang F, Hao Y, Dou J, et al. Inverse relationship between serum osteocalcin levels and visceral fat area in Chinese men. J Clin Endocrinol Metab. 2013;98:345-51.

35. Winhofer $Y$, Handisurya A, Tura A, Bittighofer C, Klein $K$, Schneider B, et al. Osteocalcin is related to enhanced insulin secretion in gestational diabetes mellitus. Diabetes Care. 2010;33:139-43.

36. Hwang YC, Jeong IK, Ahn KJ, Chung HY. The uncarboxylated form of osteocalcin is associated with improved glucose tolerance and enhanced beta-cell function in middle-aged male subjects. Diabetes Metab Res Rev. 2009;25:768-72.

37. Kanazawa I, Yamaguchi T, Yamauchi M, Yamamoto M, Kurioka S, Yano S, et al. Serum undercarboxylated osteocalcin was inversely associated with plasma glucose level and fat mass in type 2 diabetes mellitus. Osteoporos Int. 2011;22:187-94.

38. Yoshida M, Jacques PF, Meigs JB, Saltzman E, Shea MK, Gundberg $\mathrm{C}$, et al. Effect of vitamin K supplementation on insulin resistance in older men and women. Diabetes Care. 2008;31:2092-6.

39. Shea MK, Gundberg CM, Meigs JB, Dallal GE, Saltzman E, Yoshida M, et al. Gamma-carboxylation of osteocalcin and insulin resistance in older men and women. Am J Clin Nutr. 2009;90:1230-5.

40. Kumar R, Binkley N, Vella A. Effect of phylloquinone supplementation on glucose homeostasis in humans. Am J Clin Nutr. 2010;92:1528-32.

41. Vergnaud $P$, Garnero $P$, Meunier PJ, Bréart G, Kamihagi K, Delmas PD. Undercarboxylated osteocalcin measured with a specific immunoassay predicts hip fracture in elderly women: the EPIDOS Study. J Clin Endocrinol Metab. 1997;82:719-24.

42. Nimptsch K, Hailer S, Rohrmann S, Gedrich K, Wolfram G, Linseisen J. Determinants and correlates of serum undercarboxylated osteocalcin. Ann Nutr Metab. 2007;51:563-70.

43. Aonuma H, Miyakoshi N, Hongo M, Kasukawa Y, Shimada Y. Low serum levels of undercarboxylated osteocalcin in post- 
menopausal osteoporotic women receiving an inhibitor of bone resorption. Tohoku J Exp Med. 2009;218:201-5.

44. Schafer AL, Sellmeyer DE, Schwartz AV, Rosen CJ, Vittinghoff $\mathrm{E}$, Palermo L, et al. Change in undercarboxylated osteocalcin is associated with changes in body weight, fat mass, and adiponectin: parathyroid hormone (1-84) or alendronate therapy in postmenopausal women with osteoporosis (the PaTH study). J Clin Endocrinol Metab. 2011;96(12):E1982-9.

45. Levinger I, Zebaze R, Jerums G, Hare DL, Selig S, Seeman E. The effect of acute exercise on undercarboxylated osteocalcin in obese men. Osteoporos Int. 2011;22:1621-6.

46. Pollock NK, Bernard PJ, Wenger K, Misra S, Gower BA, Allison $\mathrm{JD}$, et al. Lower bone mass in prepubertal overweight children with prediabetes. J Bone Miner Res. 2010;25(12):2484-93.
47. Pollock NK, Bernard PJ, Gower BA, Gundberg CM, Wenger K, Misra S. Lower uncarboxylated osteocalcin concentrations in children with prediabetes is associated with beta-cell function. J Clin Endocrinol Metab. 2011;96:1092-9.

48. ReinehrT, Roth CL. A new link between skeleton, obesity and insulin resistance: relationships between osteocalcin, leptin and insulin resistance in obese children before and after weight loss. Int J Obes (Lond). 2010;34:852-8.

49. Ducy P.The role of osteocalcin in the endocrine cross-talk between bone remodelling and energy metabolism. Diabetologia. 2011;54:1291-7.

50. Clemens TL, Karsenty G. The osteoblast: an insulin target cell controlling glucose homeostasis. J Bone Miner Res. 2011;26(4):677-80. 